\title{
The European Union, China and Central Asia
}

Global and Regional Cooperation in a New Era

\section{Edited by}

Fabienne Bossuyt and Bart Dessein

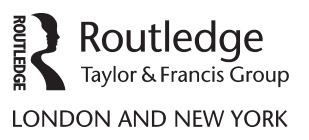


First published 2022

by Routledge

2 Park Square, Milton Park, Abingdon, Oxon OX14 4RN

and by Routledge

605 Third Avenue, New York, NY 10158

Routledge is an imprint of the Taylor \& Francis Group, an informa business

(C) 2022 selection and editorial matter, Fabienne Bossuyt and Bart Dessein; individual chapters, the contributors

The right of Fabienne Bossuyt and Bart Dessein to be identified as the authors of the editorial material, and of the authors for their individual chapters, has been asserted in accordance with sections 77 and 78 of the Copyright, Designs and Patents Act 1988.

All rights reserved. No part of this book may be reprinted or reproduced or utilised in any form or by any electronic, mechanical, or other means, now known or hereafter invented, including photocopying and recording, or in any information storage or retrieval system, without permission in writing from the publishers.

Trademark notice: Product or corporate names may be trademarks or registered trademarks, and are used only for identification and explanation without intent to infringe.

British Library Cataloguing-in-Publication Data

A catalogue record for this book is available from the British Library

Library of Congress Cataloging-in-Publication Data

A catalog record has been requested for this book

ISBN: 9780367900687 (hbk)

ISBN: 9781032121819 (pbk)

ISBN: 9781003022336 (ebk)

DOI: $10.4324 / 9781003022336$

Typeset in Times New Roman

by Deanta Global Publishing Services, Chennai, India 